\title{
MEMBANGUN BIROKRASI ANTI KORUPSI
}

\section{Oleh :}

\author{
SRI MUJIARTI ULFAH
}

\begin{abstract}
Abstrak
Korupsi menjadi masalah serius negeri ini, jika tidak dtuntaskan sampai keakar masalah akan mengakibatkan krisis kepercayaan yang akut terhadap pemerintah. Birokrasi yang bersih dan baik menjadi idaman masyarakat. Berbagai langkah reformasi birokrasi pun dilakukan seperti implementasi Teori Good Governance, yang dipertegas dengan lahirnya Reinventing Governmant bahkan New public manajement namun sampai saat ini tidak memperlihatkan progress yang signifikan, salah satunya adalah struktur birokrasi kita masih sangat gemuk sehingga mengakibatkan tidak hanya korupsi namun juga membawa efek lain yang merugikan masyarakat seperti birokrasi yang tidak produktif, tidak efisien, rendah kualitas, miskin inovasi dan kreativitas. Dengan berbagai kondisi itulah Islam mampu menjawab permasalahan tersebut.
\end{abstract}

Keywords: Good Governance, Birokrasi, Korupsi, Islam

\section{PENDAHULUAN}

Seakan tidak pernah habis, kasus korupsi baru terus bermunculan hampir setiap hari. Dalam kasus terbaru yang cukup mengguncang tanah air meskipun bagi sebagian kalangan bukan hal yang mengejutkan yakni terungkapnya persengkokolan korupsi tiga lembaga dalam pilar demokrasi eksekutif, legislative dan yudikatif. Terungkapnya fakta ini semakin memperkuat stigma negative tentang birokrasi di Indonesia.

Teori Good Governance (tata kelola pemerintahan yang baik) setelah beberapa dekade terus di dengungkan dan diterapkan seakan tidak mampu menjawab permasalahan yang terus muncul. Para pemikir duniapun berupaya mencari konsep yang mampu menyelesaikan permasalahan korupsi ditubuh birokrasi. Salah satu teori yang banyak dipraktekkan di dunia adalah new Publik Manajement.

Bisakah pemerintahan yang bersih dan baik dibangun saat ini, dimana hukum diperjual belikan, moralitas diabaikan , kemiskinan yang sistemik dan patologi birokrasi menggrogoti? Bahkan mengapa dari sekian banyak cara yang ditempuh, pemerintah Indonesia tetap berada di peringkat teratas Negara terkorup di dunia? kondisi inilah yang coba dikaji dalam tulisan dengan menggunakan kerangka, bagaimana gagasan sistem Islam dalam membangun system birokrasi yang baik dan bersih serta anti korupsi dengan perbandingan reformasi birokrasi yang di gagas pemerintah saat ini.

\section{Birokrasi Korup, Negara Bangkrut}

Birokrasi menurut kamus umum bahasa Indonesia adalah sistem pemerintahan yang dijalankan oleh pegawai pemerintah karena telah berpegang pada hierarki dan jenjang jabatan. Atau dalam definisinya yang lain, birokrasi adalah cara bekerja atau susunan 
pekerjaan yang serba lamban, serta menurut tata aturan yang banyak laku-likunya (Poerwadarminta, Kamus umum bahasa Indonesia; 1987:144.)

Menurut perspektif Administrasi Publik, birokrasi dapat di pahami sebagai Badan atau organisasi pemerintahan yang melaksanakan layanan public yang profesional, efektif, efisien, dan produktif. Birokrasi mesti melaksanakan tugas sesuai aturan, cepat, tepat, mudah, murah, dan menghasilkan. Pandangan ini diperkuat oleh Agus P \&Wahyudi K (2009) Birokrasi merupakan mesin organisasi dan kebijakan publik yang sangat penting.

Sebagai pemberi pelayanan, maka birokrasi berada di garis terdepan langsung bersinggungan dengan masyarakat, memenuhi kebutuhan masyarakat. Sehingga untuk mengukur bagaimana baik dan bersihnya pemerintah dapat melalui performance birokrasinya. Namun dari Pengalaman dan kinerja birokrasi dari berbagai Negara telah melahirkan dua pandangan yang saling bertentangan terhadap birokrasi. Pandangan pertama melihat birokrasi sebagai kebutuhan, yang akan meng-efesien-kan dan men-efektif-kan pekerjaan pemerintahan. Pandangan kedua, melihat birokrasi sebagai —musuh\| bersama, yang kerjanya hanya mempersulit hidup rakyat, sarangnya korupsi, tidak melayani, cenderung kaku dan formalistis, penuh dengan arogansi (yang bersembunyi di balik hukum) dan sebagainya.

Memang munculnya pandangan tersebut bukan tanpa alasan, karena permasalahan birokrasi tetap merupakan masalah sentral yang dihadapi oleh Negara. Padahal secara konseptual, birokrasi merupakan badan yang netral. Faktor diluar birokrasilah yang menentukan wajah birokrasi menjadi menjadi baik atau jahat, yaitu manusia yang akan menjalankan dan system yang dipakai, dimana birokrasi itu hidup dan bekerja. Artinya jika sistem (politik, pemerintahan dan sosial budaya) yang dipakai oleh suatu negara adalah baik dan pejabat birokrasi adalah orang-orang yang baik, maka birokrasi menjadi sebuah badan yang baik dan efektif. Sebaliknya, jika birokrasi hidup dalam system yang jelek, hukumnya lemah, serta ditunggangi oleh para pejabat yang tidak jujur, maka birokrasi akan menjadi buruk dan menakutkan bagi rakyatnya.

Warsito Utomo (2007) menggambarkan ketika kita mendalami dan hidup dalam aktivitas birokrasi pemerintahan, maka kita akan sangat mengenal dan familiar dengan apa yang disebut dengan bureaupathology, yakni penyakit birokrasi. Penyakit birokrasi terdiri dari birokratism dan bureaunomia.

penyakit birokratism merupakan penyakit birokrasi yang berkaitan dengan pelayanan pemerintah yang menyangkut system prosedur yang sangat berbelit-belit, memakan waktu, biaya dan tenaga. Sedangkan bureaunomia tidak saja mempengaruhi pelaksanaan tekhnis operasional pemerintahan, tetapi lebih berpengaruh terhadap derajat tingkat kebijakan pemerintah atau formulasi kebijakan pemeritah.

Bureaunomia dilakukan oleh kekuatan-kekuatan politik untuk mempengaruhi birokrasi pemerintahan didalam melayani masyarakat. Bureaunomia menanamkan pengaruhnya didalam birokrasi pemerintahan dengan mendudukkkan orang-orang partai yang bukan birokrasi profesional didalam jajaran birokrasi ataupun memberikan privilege pada aparat birokrasi yang berafiliasi dengan kekuatan partainya.

Dampak yeng terjadi dengan adanya bureaunomia adalah, pertama, birokrasi dan birokrat kita menjadi tidak netral lagi. Formulasi dan implementasi kebijakan lebih ditentukan oleh kekuatan dapur politik partai daripada dapur pemerintahan. Kedua, birokrasi dan birokrat kita lebih berorientasi kepada kepentingan keinginan partai politik daripada komponen perangkat daerah. Ketiga, birokrat dan birokrasi melakukan tindakan-tindakan 
yang tidak elegant sesuai dengan profesionalismenya, tetapi bergerak seperti massa sebagaimana politik praktis (Warsito, 2007).

Indikator buruknya kerja birokrasi pada mumnya berfokus pada terjadinya korupsi. Korupsi atau rasuah adalah tindakan pejabat publik, baik politisi maupun pegawai negeri, serta pihak lain yang terlibat dalam tindakan itu yang secara tidak wajar dan tidak legal menyalahgunakan kepercayaan publik yang dikuasakan kepada mereka untuk mendapatkan keuntungan sepihak. (ti.or.id).

Jenis tindak pidana korupsi di antaranya; memberi atau menerima hadiah atau janji (penyuapan); penggelapan dalam jabatan; pemerasan dalam jabatan; ikut serta dalam pengadaan (bagi pegawai negeri/penyelenggara negara), dan menerima gratifikasi (bagi pegawai negeri/penyelenggara negara). Titik ujung korupsi adalah kleptokrasi, yang arti harafiahnya pemerintahan oleh para pencuri, dimana pura-pura bertindak jujur pun tidak ada sama sekali.

Menurut Transparansi Internasional, korupsi di Indonesia selama tahun 2012 menjadi perhatian dunia. Indonesia bahkan tergabung dalam 60 besar negara terkorup di dunia. Indonesia duduk di peringkat 118 dari daftar peringkat indeks persepsi korupsi 174 negara dunia. Namun jika mengacu poin tiap negara, Indonesia duduk di posisi 56 negara terkorup. (cpi.transparency.org, 29/10/13).

Bahkan dengan lebih spesifik, Salah satu survey yang dilakukan oleh Transparency International dalam Global Corruption Barometer 2013 yang melibatkan 114.000 orang di 107 negera di dunia. 3.8 persen masyarakat dunia menganggap partai politik merupakan lembaga terkorup di dunia , diikuti lembaga Kepolisian (3.7 persen), kemudian pejabat publik dan legislator (3.6 persen) (2013_Global Corruption Barometer). Begitupun halnya di Asia Tenggara, 3.9 persen masyarakat Asia tengaggara menganggap bahwa lembaga Kepolisian sebagai lembaga terkorup, diikuti Partai Poitik (3.6 persen), pejabat Publik (3.5 persen), peradilan (3,4 persen) dan parlemen (3.3 persen). Dalam hasil survey tersebut juga menjelaskan, tiga dari empat orang yang disurvey dalam Global Corruption Barometer (GCB) menyatakan bahwa korupsi di negara-negara Asia Tenggara memburuk. Suap dan penyalahgunaan wewenang masih marak, sementara lembaga-lembaga yang mestinya memberikan pelayanan, pelindungan dan supervisi justru memiliki integritas yang buruk. Di Indonesia, 72 persen warga menyatakan korupsi meningkat. Sementara 20 persen menyatakan kondisi sama dan hanya 8 pesen menyatakan korupsi menurun. Ketika ditanya tentang upaya pemberantasan korupsi, 65\% warga menyatakan belum efektif, sementara hanya 32 pesen yang menyatakan sudah efektif. Sisanya tidak yakin apakah efektif atau tidak. Ini semakin memperkuat bahwa korupsi di sektor publik sudah menjadi hal yang sangat komplek.

Menurut Andhi Nirwanto (Jaksa Agung Muda Tindak Pidana Khusus) pada tahun 2011 antara bulan januari-Agustus Jumlah perkara tindak pidana korupsi di Tanah Air yang memasuki tahap penyidikan mencapai 1.018 kasus. (republika.co.id/ 4/11/13).

Dari data tersebut, memperlihatkan bagaimana maraknya kasus korupsi yang ada selama ini seperti teori gunung es, karena jika dilihat dipermukaan lebih sedikit dibanding apa yang ada didasarnya. Sehingga ketika kita meyaksikan berbagai kasus besar terangkat ke publik, seperti kasus Hambalang, kasus simulator SIM, dan kasus Impor daging Sapi serta kasus jual beli perkara di MK dan jual beli hasil pemilu di MA hanyalah sebagian kasus, padahal beberapa kasus korupsi dari dulu sampai sekarang tidak pernah tuntas, seperti pembuatan KTP, SIM, dan Paspor, terus menjalankan praktek secara bebas. Sehingga wajar 
jika masyarakat menganggap memberi_saweran` kepada aparat pemerintah untuk melicinkan urusan menjadi budaya.

Akibatnya kebangkrutan birokrasi, sebagai akibat korupsi dimana-mana, baik dinegara maju atau negara terbelakang. David Osborn dan Ted gaebler (mewirausahakan Birokrasi, Pustaka Biraman Pressindo, 2005) mensinyalir bagaimana birokrasi Amerika, yang 100 tahun lalu dipandang positif, kini semakin dirasakan lamban, tidak lincah, tidak bisa menyesuaikan dengan perubahan kebutuhan masyarakat. Birokrasi kota-kota yang ada di Amerika menjadi demikian gemuk dan korup, sehingga tidak bisa diharapkan lagi.

Indonesia termasuk Negara yang memiliki birokrasi tergemuk di dunia, bahkan Menurut Forum Indonesia untuk Transparansi Anggaran (FITRA) menyebut era pemerintahan Presiden Susilo Bambang Yudhoyono (SBY), gemar membentuk lembaga dan mengangkat tim ahli yang justru membuat gemuk birokrasi. Selama Presiden SBY menjabat pada 2004, ada 105 lembaga non-struktural, 80 persen dibentuk oleh Keputusan Presiden (Keppres). 99 lembaga non struktural ini menyerap anggaran mencapai $\mathrm{Rp} 2,4$ triliun per tahun (.merdeka.com, 3/9/13).

Dampak lain dari korusi adalah bagi kesejahtaraan, seperti apa yang di sampaikan oeh Abraham Samad (Ketua KPK), Indonesia adalah negeri yang kaya dan memiliki pemasukan besar. Dari sektor energi misalnya, negara bisa saja mendulang Rp 15 ribu triliun setiap tahun. Uang sebesar itu akan di dapat jika pemerintah mampu memaksa perusahaan tambang untuk membayar royalty sebesar 50 persen. Sebagai contoh, dalam setahun, Blok migas Mahakam bisa mendulang Rp 120 triliun, Blok Cepu sebesar Rp 190 triliun, dan Blok Madura senilai Rp 135 triliun. Kenapa pemerintah tidak bisa memaksa? Karena pengusaha telah membayar sogokan kepada pemerintah setempat. "Bahkan, sesungguhnya uang suap yang dibayarkan ke oknum pemerintah lebih besar dari royalti," ucapnya. (Tempo.co, 29/10/13). Beliau pun menambahkan seandainya uang sebanyak itu di bagikan kepada rakyat Indonesia maka tiaptiap kepala keluarga akan memilikik penghasilan sekitar Rp 30 juta setiap bulan.

\section{Reformasi Birokrasi}

Menurut Eko Prasojo Wakil Menteri Pendayagunaan Aparatur Negara dan Reformasi Birokrasi (Wamen PAN dan RB). Ada tujuh realita kebobrokan birokrasi di Indonesia. pertama, pola pikir para birokrat terlalu sesuai aturan. Kedua, orientasi budaya kerja lemah. Ketiga, birokrasi secara organisasi terlalu gemuk. Keempat, perundang-undangan tidak harmonis. Kelima, banyak para birokrat ditempatkan pada posisi yang tidak sesuai kemampuannya. Keenam, kewenangan yang tumpang tindih atau overlapping. Ketujuh, pelayanan publik menjadi buruk. Selain itu, kuatnya ikatan antara para birokrat atau birokrasi dengan political authority; diorganisir secara hierarkis dan birokratis; serta memiliki monopoli. Hal tersebutlah yang menciptakan apa yang dinamai dengan budaya birokrasi.

Menurut mantan Menteri Negara Pendayagunaan Aparatur Negara, Ryaas Rasyid. Saat ini masalah terbesar bagi Indonesia adalah manajemen organisasi yang buruk, sehingga korupsi terus berjalan meskipun ada upaya pemerintah untuk memberantasnya. Sistem tata kelola organisasi yang tidak resisten terhadap penyimpangan dan penyelewengan itu, menjadi sarang persembunyian yang paling aman bagi para koruptor. "Indonesia memiliki struktur birokrasi yang paling gemuk di dunia, tidak ada tanda-tanda keberhasilan reformasi birokrasi jika perampingan organisasi tidak dilaksanakan," kata Ryaas.(Facebook.com, 21/3/12). 
Dampak dari gemuknya struktur birokrasi di Indonesia menyebabkan cenderung permisif terhadap korupsi dan pungutan liar (high cost economy). dan menyebabkan pelayanan masyarakat menjadi tidak efisien karena banyaknya meja birokrasi (perijinan) yang harus dilalui. sehingga pemakai jasa terdorong memberikan —uang jasall agar urusan birokrasinya dapat dipercepat.

Secara umum, korupsi mengikis kemampuan institusi dari pemerintah, karena pengabaian prosedur, penyedotan sumber daya, dan pejabat diangkat atau dinaikan jabatan bukan karena prestasi. Pada saat yang bersamaan, korupsi mempersulit legitimasi pemerintahan. Sehingga ditempuhkan program pemerintah yakni reformasi Administrasi. Tujuan dari reformasi birokrasi adalah untuk mewujudkan pemerintahan yang bersih dari KKN, pelayanan yang prima dan akuntabel khususnya dalam masyarakat dan dunia usaha.

Berbagai teori di munculkan untuk memperbaiki birokrasi di dunia tak terkecuali Indonesia. Pada awal tahun 1990an good governance masuk ke Indonesia sebagai solusi dari permasalahan birokrasi yang akut. Menurut Sjamsiar $(2005,3)$ sebelum wacana good governance mendominasi arah reformasi pemerintahan di Indonesia, terminology seperti - less-governmentl, - enterpreneural Government\| dan sejenisnya sempat menjadi wacana yang dominan. Buku yang ditulis oleh Ted Gaebler dan David Osborn (1992), yaitu -reinventing government\|l telah menjadi rujukan bagi birokrasi di Indonesia dalam menyelenggarakan pemerintahan dengan sepuluh prinsipnya.

Beberapa tahun kemudian, teori Good Governance mengalami perkembangan dengan model New Public Manajement (NPM). NPM merupakan teori baru manajemen pubik yang beranggapan bahwa praktik manajemen sektor swasta adalah lebih baik dibandingkan dengan praktik manajemen sektor publik. Huges dkk. dalam Mahmudi (2010) Dalam Febriyanto (2013) mengatakan bahwall untuk memperbaiki kinerja sektor publik perlu diadopsi beberapa paktik dan tekhnik manajemen yang diterapkan di sektor swasta kedalam organisasi sektor publik, seperti pengadopsian mekanisme pasar, kompetensi tender, dan privatisasi perusahaanperusahaan publik.

Mengenai New Public Manajement Anthony B.L. Cheung, dalam Hermawan (2013) mengatakan bahwa tidak akan dengan mudah merubah secara mendasar posisi birokrasi sebagai salah satu kekuatan politik dan menggantinya dengan — public service delivery\| yang menempatkan warganegara sebagai konsumen (customers is the king).

Prasojo dkk. Dalam Kurniawan (2007) menjelaskan mengenai pergeseran kata antara kewarganegaraan dengan konsumen. Seiring dengan diadopsinya pendekatan berorientasi pasar dalam new public manajement menyebabkan masyarakat diredefinisi sebagai konsumen atau klien dan karenanya memiliki implikasi terhadap pola hubungan antara pemerintah dengan masyarakat (Haque, 1999, 313). Dalam pola hubungan yang baru tersebut melibatkan adanya transaksi keuangan antara masyarakat dengan pemerintah dalam proses penyediaan pelayanan publik (Haque, 1999, 313). Karenanya menurut Haque (1999, 313) Dalam Kurniawan (2007), kondisi yang semacam ini khususnya di negara berkembang dapat merugikan bagi kelompok masyarakat miskin yang tidak memiliki kapasitas keuangan sebagai konsumen atau pengguna pelayanan.

Dengan melihat berbagai teori dan konsep diatas, maka kita bisa simpulkan bagaimana upaya dunia untuk membangun birokrasi yang sehat ternyata malah melahirkan berbagai teori dan konsep yang keluar dari esensi masalah. Karena salah satu masalah birokrasi adalah korupsi sedangkan solusi yang ditawarkan adalah dengan mengubah konsep 
pelayanan publik yang dipegang pemerintah di serahkan kepada swasta. Padahal tidak ada yang bisa menjamin kalau swasta tidak melakukan korupsi.

Indonesia sebagai Negara emerging markets dalam Survei yang dilakukan oleh Political \& Economic Risk Consultancy yang berbasis di Hongkong, menjadikan Indonesia sebagai negara paling korup dari 16 negara di kawasan Asia Pasifik menurut survei persepsi korupsi 2011 terhadap pelaku bisnis. (kompas.com. 4/11/2013). Di negara-negara berkembang, politisi dan pejabat pemerintah menerima suap dari kelompok swasta sebanyak 20 sampai 40 miliar US dolar atau setara dengan Rp 200 triliun sampai Rp 400 triliun setiap tahun. Suap itu dilakukan dengan cara terorganisasi dan nyaris tidak tersentuh hukum. Akibat korupsi oleh kelompok bisnis ke pejabat publik, harga yang dibayar tidak sekadar uang. Praktik itu secara langsung telah merusak kinerja perusahaan. Imbasnya, terjadi korupsi pasar yang melemahkan persaingan sehat, harga yang adil, dan efisiensi. Dampak terburuk lain adalah mempertahankan birokrasi, partai politik, dan pemerintahan yang korup (antikorupsi.org, 14/10/09).

Di negara-negara berkembang, politisi dan pejabat pemerintah menerima suap dari kelompok swasta sebanyak 20 sampai 40 miliar US dolar atau setara dengan Rp 200 triliun sampai Rp 400 triliun setiap tahun. Suap itu dilakukan dengan cara terorganisasi dan nyaris tidak tersentuh hukum. Akibat korupsi oleh kelompok bisnis ke pejabat publik, harga yang dibayar tidak sekadar uang. Praktik itu secara langsung telah merusak kinerja perusahaan. Imbasnya, terjadi korupsi pasar yang melemahkan persaingan sehat, harga yang adil, dan efisiensi. Dampak terburuk lain adalah mempertahankan birokrasi, partai politik, dan pemerintahan yang korup (antikorupsi.org, 14/10/09).

Berdasarkan penelitian Smith dalam Utomo (2007. 205-206), terdapat berbagaia faktor penyebab buruknya pelayanan aparat birokrasi, antara lain: gaji yang rendah, sikap mental aparat pemerintah, kondisi ekonomi yang buruk; Administrasi yang lemah; dan kurangnya pengawasan, sehingga dari sisi inilah kita bisa melihat bahwa buruknya pelayanan birokrasi karena disebabkan oleh faktor-faktor yang saling terkait bukan disebabkan oleh faktor tunggal.

Sepriyanto (2002, 252-255) mengungkapkan bahwa setidaknya ada dua factor yang menyebabkan korusi, yaitu: Faktor Individu, Paham materialism yang menjadikan harta sebagai tujuan hidup telah mengakar dalam diri individu bahkan juga Negara. Paham ini menyebabkan hilangnya budaya malu, rasa bersalah sekaligus pengendalian diri, menghadapi fenomena korupsi. Bahkan pada tingkatan tertentu, korupsi dipandang cara yang sah untuk bagi-bagi‘ rejeki, menjaga stabiitas masyarakat, serta alat untuk mengendalikan dukungan dan kesetiaan (politik). Tidaklah heran kalau kita lihat saat ini korupsi dilakukan secara berjama'ah.

Tentu saja, permasalahan individu ini tidak berdiri sendiri, karena menurut Ryaas Rasyid -korupsi yang telah mengakar di birokrasi pemerintah saat ini merupakan produk dari sistem administrasi yang sakitl. Pola pendidikan yang materialisme, tata nilai (sosial, kemasyarakatan, keluarga) yang liberal, system ekonomi yang materialism, sehingga sistem sosial yang dibangun akan membentuk individu-individu yang mengagungkan harta dan kekayaan sebagai sumber hidunya. Sehingga lahirlah masyarakat yang individualistik sekaligus materialistic. Dan saat ini kita hidup dalam kondisi ini.

Faktor system, Besar kecilnya birokrasi dan wewenangnya, ditentukan oleh fungsi pemerintahan yang didefinisikan oleh system politik dan pemerintahan yang dipakai negara tersebut. Factor system yang rusak tidak hanya disebbakan oleh ideology yang rusak namun 
disebabkan implementasi system hukum yang lemah. System saat ini tidak menjalankan fungsinya sebagai lembaga pencegah korupsi namun juga ketidakmampuanya untuk memberikan efek jera bagi orang yang melakukan korupsi. Penegakan hukum setengah hati atas kasus-kasus korupsi bukan saja membuat para koruptor takut, tetapi juga sekaligus membuat penghormatan terhada hukum rendah. Sebagai contoh, di kota palangkara ketua DPRD kota sudah menjadi tersangka kasus korupsi Rp 2 miliar APBD kota Palangkaraya, namun karena dia anak pejabat dan keponakan pejabat samapai saat ini pihak kejaksaan tidak bersikap tegas, dan sampai saat ini belum menjalani hukuman.

Kitapun tidak dapat memungkiri system penggajian yang rendah menjadi salah satu sebab kelemahan system ini. Gemuknya struktur birokrasi kita menyebabkan tersedotnya anggaran pada belanja pegawai. Meskipun setiap tahun pemerintah melakukan remunerasi gaji PNS namun tidak diimbangi dengan pertumbuhan ekonomi sector riil tetap saja kesejahteraan hanya sebatas mimpi.

Sistem Sosial. Ditengah masyarakat yang menerapkan ideology kapitalisme saat ini nilai sosial yang hidup ditengah masyarakat adalah niali-nilai pragmatism, materialism, dan permissive. Sehingga menyebabkan Control sosial yang lemah. Strata yag berlaku dimasyarakat tetap antara si kaya dan si miskin tanpa melihat halal atau haram harta yang diperoleh. Kita tidak heran saat ini jika melihat ulama menjadi guru spiritual pejabat yang korup.

\section{Gagasan Islam Dalam Membangun Birokrasi Anti Korupsi}

Dari tahun 623-1924M, Islam diterapkan dalam sebuah Institusi Negara yang bernama Khilafah Islamiyah. Carleton, Ceo Hewwlett Packard, dengan jelas menggambarkan dengan mengatakan: \|bahwa Peradapan Islam merupakan peradapan terbesar di dunia. Peradapan Islam sanggup menciptakan negara adidaya dunia (superstate) terbentang dari satu samudera ke samudera yang lain. Dari iklim utara hingga tropis dengan ratusan juta orang didalamnya, dengan perbedaan kepercayaan dan sukull.

Pola yang dibangun untuk mencegah terjadinya korupsi di birokrasi. Hal ini tergambar dari Sabda Rasulullah SAW, sebagai nabi dan pemimpin negara di Madinah:

-Hadiah yang diberikan kepada para penguasa adalah Suht (haram) dan suap yang diterima hakim adalah kufur.l (HR. Ahmad).

Beberapa aturan yang diterapkan oleh pemimpin Islam di dalam di dalam Daulah Khilafah seperti; Penghitungan Kekayaan. Khalifah Umar Bin Khattab memberikan contoh teladan dalam pencegahan korupsi. Beliau akan menghitung kekayaan seseorang diawal jabatannya sebagai pejabat Negara, kemudian menghitung ulang diakhir jabatannya. Bila terdapat kenaikan yang tidak wajar, beliau akan memerintah untuk menyerahkan kekayaan tersebut ke Baitul Mall (tempat penyimpanan kekayaan negara) atau membagi dua harta tersebut.

Keteladanan pemimpin. Berbagai cerita keteladan Nabi Muhammad SAW, dan para sahabat dalam menjalani kehidupan ini. Rasulullah SAW sebagai pemimpin tertinggi kaum muslimin menjalani kehidupan dengan penuh kesehajaan, tidurnya beliau diatas pelepah kurma, kebiasaan beliau diikuti oleh sahabat-sahabat beliau, bahkan Umar Bin Khattab terbiasa memakai pakaian yang penuh dengan tambalan. Kesehajaan mereka mejalani kehidupan ini berbanding lurus dengan kebijakan yang mensejahterakan masyarakat. Pemimpin deperti inilah yang akan menjadi teladan, baik bagi para birokrat bawahannya, maupun bagi rakyatnya. 
Penegakan Hukum yang Tegas. Khalifah Umar bin Khattab Ketika melihat seekor unta gemuk milik Abdullah Bin Umar, (anak beliau) di pasar, beliau menyitanya. Karena beliau mengetahui, unta anaknya itu gemuk karena digembalakan bersama unta-unta milik Baitul Mal di padang gembalaan milik Negara. Ketegasan beliau dalam memberantas korupsi menjadikan masa kepemimpinan beliau melahirkan kemakmuran. Dalam system khilafah, selain sangsi pemiskinan, juga dapat dihukum tasyir, yaitu berupa pewartaan atas diri koruptor yang dieksos oleh media massa, Atau, bisa juga sampai hukuman kurungan. Menurut Abdurrahman alMaliki dalam kitab Nidzamul Uqubat fil Islam (hlm. 190), hukuman kurungan koruptor mulai 6 bulan sampai 5 tahun. Namun, masih dipertimbangkan banyaknya uang yang dikorup. Bila mencapai jumlah yang membahayakan ekonomi negara, koruptor dapat dijatuhi hukuman mati.

Keimanan Individu merupakan control efektif agar tidak terjerumus dalam korupsi. Dengan iman akan tercipta mekanisme pengendalian diri yang andal. Dengan iman pula para birokrat, juga semua rakyat, akan berusaha keras untuk mencari rizki secara halal dan memanfaatkannya hanya di jalan yang di ridhai Allah SWT. Teladan ini di contohkan oleh Abdullah bin Rawahah. Ketika beliau sedang menjalankan tugasnya, orang-orang Yahudi datang kepadanya. Mereka mengumpulkan perhiasan isteri-isteri mereka untuk menyuap Abdullah bin Rawahah. Mereka berkata,\|Ini untukmu dan ringankanlah pungutan yang menjadi beban kami. Bagilah kami lebih dari separuhll. Abdullah bin Rawahah menjawab,

\|Hai orang-orang Yahudi, dengarkanlah! Bagiku, kalian adalah makhluk yang paling dimurkai Allah. Aku tidak akan membawa perhiasan itu dengan harapan aku akan meringankan pungutan yang menjadi kewajiban kalian. Suap yang akan kalian berikan ini sesungguhnya merupakan 'suht' (harta haram). Sungguh, kami tidak akan memakannnya.\| Mereka kemudian berkomentar, \|karena sikap seperti inilah, langit dan bumi ini akan tetap tegak\|.

Sistem Kontrol yang kuat. Allah SWT berfirman; - hendaknya ada diantara kalian, sekelompok umat yang mengajak kepada kebaikan serta menyeru kepada kema'rufan dan mencegah dari kemungkaran\| (QS. Ali _Imran: 104).

Dari Ummu_Atiya dari Abi Sa‘id yang menyatakan Rasulullah SAW bersabda :

—sebaik-baik jihad adalah (menyatakan) kata-kata yang haq di depan penguasa yang Lalimll. (HR. Ahmad).

Selain itu, Sistem birokrasi dan administrasi dalam kekhilafahn dibangun berdasarkan Falsafah: jika ada orang yang mempunyai kesulitan, maka hendaknya dilihat bagaimana memudahkannya. Dalam Sitem birokrasi Islam pun mempunyai ciri khas, yaitu basathah fi annizham (sistemnya sedehana), sur'ah fi injaz (Cepat selesai) dan kifayah fi man yatawalla (cukup pelaksananya).(Abdullah, Studi Pemikiran Islam: 81). Dengan ketiga ciri khas tersebut, semua urusan rakyat bisa tertangani dan terselesaikan dengan baik dan cepat. Juga bisa mencegah terjadinya korupsi dan suap disetiap lini. Sebab, ciri khas orang yang membutuhkan pelayanan biasanya ingin cepat diselesaikan. Jika sistem birokrasinya bertele- tele, maka ini akan membuka pintu terjadinya suap dan korupsi. Selain itu birokrasi dan administrasi negara juga tidak bersifat sentralistik, tetapi desentralistik. Di tiap kota kecil atau kota besar ada biro administrasi, yang memungkinkan penduduk setempat menyelesaikan urusan administrasi cukup ditempatnya, tidak perlu harus merujuk ke pusat. Ketegasan tindakan praktis ini menjadi ciri khas keseriusan kekhilafahan dalam menangani masalah rusaknya Birokrasi. 


\section{PENUTUP}

Berbagai langkah strategis dilakukan oleh pemerintah untuk membangun birokrasi agar bersih dan anti tehadap korupsi. Namun, berbagai langkah tersebut tetap menghadapi kendala dan tantangan yang tidak mudah. Kita berharap agar langkah-langkah strategis tersebut memberi perbaikan bagi negara kita yang sedang mengalami krisis ketidakpercayaan terhadap penanganan kasus korupsi dinegeri ini.

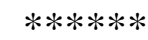

\section{DAFTAR PUSTAKA}

Al-Maliki, Abdurrahman. Sistem sanks Dalam Islami. PTI. Jakarta. 2002

Anonim, Bunga Rampai Syari'at Islam. HTI.Jakarta. 2002

Jurnal Ilmiah Administrasi Publik \& Pembangunan, Edi Hermawan. New Publik Management dan Politik Birokrasi dalam Reformasi Birokrasi di Indonesia. Edisi Juli- Desember 2013

Jurnal. Iwan Ismi Febriyanto. Dialektika Kebijakan Publik: "Studi Komparasi dan teori New Public Manajement dengan Good Governance dalam Persfektif Kebijakan Publik. 20013

Jurnal Ilmu Adm Negara. Teguh Kurniawan. Pergeseran Paradigma Administrasi Publik: Dari Perilaku Model Klasik dan Npm ke Good Governancemore. Edisi 1 Januari 2007,

Kumorotomo, Wahyudi\&Pramusinto, Agus, Governance Reform di Indonesia. Gava Media, Yogyakarta, 2009

Osborn, David \& Gaebler,Ted. Reinventing Government. PPM. Jakarta. 2005.

Sinambela, Lijan Poltak, Reformasi Pelayanan Publik. Bumi Aksara, Jakarta. 2008

Sjamsudin, Syamsiar. Pemerintahan dan Kemitraan. Yayasan Pembangunan Nasional. Malang. 2005

Utomo, Warsito. Administrasi Publik Baru Indonesia. Pustaka Pelajar. Yogyakarta. 2007.

Website

http://issuu.com/transparencyinternational/docs/2013_globalcorruptionbarometer_en/25?e=2 496456/3903358.

http://www.tempo.co/read/news/2013/10/21/092523493/Tanpa-Korupsi-Gaji-Rakyat-BisaRp-30-Juta-Sebulan

http://www.merdeka.com/uang/birokrasi-terlalu-gemuk-instansi-apa-yang-perludihilangkan.html 
https://www.facebook.com/notes/icmi-ikatan-cendekiawan-muslim-se-

indonesia/ryaas- rasyid-berantas-korupsi-cukup-tiga-tahun/10150773641434225

http://finance.detik.com/read/2013/05/16/105049/2247520/4/wamenpan-ungkap-

7- kebobrokan-birokrasi-di-indonesia

www.ti.or.id

http://nasional.kompas.com/read/2012/02/22/154133

95,

http://www.republika.co.id/berita/nasional/umum/11/09/12/lrevtp-perkara-korupsidi- indonesia-mencapai-1018-kasus,

http://www.antikorupsi.org/id/content/korupsi-di-sektor-swasta. Emerson Yuntho. tulisan ini disalin dari Jawa Pos, 14 Oktober 2009. 